\title{
Psychometric examination of a Brazilian adaptation of the Expressions of Spirituality Inventory - Revised
}

Leonardo Xavier de Lima e Silva. Universidade Federal de Pernambuco.

Douglas A. MacDonald. University of Detroit Mercy.

Djailton Pereira da Cunha. Universidade Federal de Pernambuco.

Aurino Lima Ferreira. Universidade Federal de Pernambuco.

\begin{abstract}
Using a sample of 493 adults, the present investigation examined the psychometric properties of a Brazilian adaptation of the Expressions of Spirituality Inventory- Revised (ESI-R; MacDonald 2000a), a measure of an empirically derived five dimensional model of spirituality which has been shown to have some promise for cross-cultural research. Reliability analysis indicated that the ESI-R dimensions produced satisfactory inter-item consistency coefficients. Exploratory factor analysis provided evidence generally supportive of the replicability of the five dimensions. Confirmatory factor analysis testing two competing factor models (four versus five factor) provided some support for both models. However, the five factor model emerged superior. Support for both convergent and discriminant validity of the ESI-R dimensions was also obtained. Overall, the findings of this study are consistent with those seen with samples from other cultures and suggest that the ESI-R holds promise for use in spirituality research in Brazil.
\end{abstract} Keywords: spirituality; assessment; psychometric; cross-cultural.

\section{Resumo}

Exame das propriedades psicométricas de uma adaptação brasileira do Expressions of Spirituality Inventory - Revised. Utilizando uma amostra de 493 adultos, a presente investigação examinou as propriedades psicométricas de uma adaptação brasileira do Expressions of Spirituality Inventory- Revised (ESI-R; MacDonald 2000a), um teste empiricamente derivado de um modelo de espiritualidade de cinco fatores que tem se mostrado promissor para a pesquisa transcultural. Análises de fidedignidade indicaram que as dimensões do ESI-R produziram coeficientes satisfatórios de consistência inter-item. As análises fatoriais exploratórias apresentaram resultados gerais favoráveis à replicabilidade das cinco dimensões. As análises fatoriais confirmatórias, testando dois modelos fatoriais concorrentes (quatro versus cinco fatores), proveram algum suporte para ambos os modelos. Apesar disso, o modelo de cinco fatores emergiu como superior. Evidências para as validades convergente e discriminante do ESI-R também foram encontradas. No geral, os achados deste estudo são consistentes com aqueles observados em amostras de outras culturas e sugerem que o ESI-R se mostra promissor para o uso na pesquisa em espiritualidade no Brasil.

Palavras-chave: espiritualidade; avaliação; psicometria, transcultural.

\section{Resumen}

El examen de las propiedades psicométricas de una adaptación brasileña del Expressions of Spirituality Inventory - Revised. Utilizando una muestra de 493 adultos, el presente estudio examinó las propiedades psicométricas de una adaptación brasileña de las expresiones del Expressions of Spirituality Inventory - Revised (ESI-R, MacDonald 2000a), una prueba derivada empíricamente de un modelo espiritual de cinco factores que han demostrado prometedor para la investigación transcultural. Análisis de confiabilidad indicaron que las dimensiones del ESI-R produjeron coeficientes satisfactorios de consistencia inter-ítem. El análisis factorial exploratorio mostró resultados favorables para la aplicación general de las cinco dimensiones. El análisis factorial confirmatorio proporcionaran algún apoyo para ambos modelos al probar dos modelos de factores concurrentes (cuatro a cinco factores). Sin embargo, el modelo de cinco factores era superior. También obtuvo evidencia de validez convergente y discriminante de las dimensiones ESI-R. En general, los resultados de este estudio son consistentes con los observados con muestras de otras culturas y sugieren que lo ESI-R se muestra prometedor para su uso en la espiritualidad de la investigación en Brasil.

Palabras clave: espiritualidad; evaluación; psicometría; transcultural. 
For research in Brazil, an ethnically diverse country known to demonstrate high rates of religious involvement (Moreira-Almeida, Pinsky, Zaleski, \& Laranjeira, 2010), there are few well validated instruments available to evaluate spirituality and related constructs (Carvalho, Taunay, \& Gondim, 2012). For example, a systematic review completed by Lucchetti, Lucchetti and Vallada (2013) identified a total of 20 tests that are available in Portuguese of which 15 have been translated and adapted from another language (mostly English). However, only eight out of the 20 tests are designed to measure spirituality rather than explicit religious concepts (e.g., attitudes toward Christianity). Further, the majority of these tests do not provide a well grounded assessment of general spirituality but instead measure specific constructs such as spiritual well-being, spiritual coping, spiritual attitudes, and spiritual experiences. Finally, as noted by Lucchetti and colleagues, none of these tests have been comprehensively evaluated and shown to have sound psychometric properties when used with Brazilian samples.

More recently, Curcio, Lucchetti and MoreiraAlmeida (2015) have published a study reporting on an initial validation of a Portuguese version of the Brief Multidimensional Measure of Religiousness/Spirituality (BMMRS-P). Using both clinical and non-clinical samples, Curcio et al. (2015) found evidence of adequate reliability (test-retest) and fairly good support for internal, convergent and discriminant validity of the various BMMRS-P scales. Unfortunately, the BMMRS-P is not a theory driven measure nor does it have an empirically grounded organizational structure. It is a syncretic amalgam of 11 scales measuring various concepts that were deemed important for health research by a working group assembled by the National Institute on Aging and the Fetzer Institute in the United States (see Fetzer Institute, National Institute on Aging Working Group, 1999). As importantly, Curcio et al. (2015), do not directly evaluate the extent to which the BMMRS-P is actually capturing the constructs with Brazilian respondents in a manner which shows equivalence to that seen in American samples (i.e., they do not examine structural/configural and measurement invariance in a rigorous manner). Consequently, while their findings are promising and provide support for further psychometric research on the BMMRS-P, they fall short of supplying strong evidence of cross-cultural validity and investigators using the test with Brazilians should exercise caution in how they interpret its scores with
Brazilian respondents. Thus, there is still a need for a well developed and validated measure of spirituality for use in Brazil.

One instrument which appears to hold promise is the Expressions of Spirituality Inventory-Revised (ESI-R; MacDonald 2000a). The ESI-R is a short version of the Expressions of Spirituality Inventory (ESI; MacDonald 2000a, 2000b), a 100 item self-report questionnaire created to operationalize an empirically derived five dimensional model of spirituality. The model itself was constructed through a series of conjoint analyses involving a total of 19 available measures of spirituality and related constructs using data obtained from two samples of Canadian university students. MacDonald's (2000b) impetus for creating the model came from his recognition that there was a profusion of competing theories and measurement tools appearing in the literature but no scientific basis for coherently organizing them and associated research findings regarding the implications for spirituality to health and functioning. The model can be understood as reflecting the latent dimensions of spirituality as embodied in extant assessment tools which according to MacDonald's (2000b) can serve as an empirically based comprehensive structural framework for understanding and studying the construct.

Since their development, the ESI and ESI-R have been used in several studies examining the relation of spirituality to a variety of health, personality, and psychosocial variables (e.g., Affeldt \& MacDonald, 2010; Bliss 2011; Heinz \& Baruss, 2001; Huber \& MacDonald, 2012; MacDonald \& Holland, 2002a, 2002b, 2003; Mendez \& MacDonald, 2012; Migdal \& MacDonald, 2013; Saucier $\&$ Skrzypinska, 2006) and the measures and factor model itself have proven fruitful for the purposes of test validation and theory development (e.g., Kassab \& MacDonald, 2011; MacDonald, 2009; MacDonald \& Holland 2002c). Of particular importance to the present study, the ESI-R has also been the focus of fairly extensive cross-cultural research with findings suggesting that the instrument shows good psychometric properties across cultures and languages. For instance, it has been studied with samples from Canada, Czech Republic, India, Japan, Korea, Malaysia, Poland, Slovakia, Spain, Switzerland, Uganda, and the United States (Gabriel \& Jezek, in press; Muhamad, Roodenburg, \& Moore, 2014; Lopez, Jodar, \& MacDonald, in press; MacDonald et al., 2015; Proyer \& Laub, 2015). In all cases, the ESI-R has demonstrated acceptable reliability and validity, though 
as MacDonald et al. (2015) note, it has not been shown to be culturally invariant (i.e., the way in which the constructs embodied by each of the five dimensions are expressed through their quantitative scores appears to differ as a function of culture and thus may be argued as being conceptually non-equivalent). The lack of support for measurement invariance across culture, however, is not onto itself particularly surprising; there is compelling evidence indicating that the findings in many areas of psychology differ as a function of culture (e.g., see Henrich, Heine, \& Norenzayan, 2010). What is important is that the ESI-R has been the focus of rigorous cross-cultural research and seems to be a good instrument to evaluate within a Brazilian context.

For the present study, we aimed to investigate the psychometric properties of the ESI-R after it was translated into Brazilian Portuguese and adapted for use with Brazilian respondents. We were most interested in examining its reliability and validity with specific attention given to its factorial validity, criterion validity, and convergent and discriminant validity. In general, we expected the ESI-R to produce evidence of acceptable reliability and validity.

\section{Method}

\section{Participants}

The sample used for the present investigation was initially made up of 533 volunteers comprised of 391 women and 138 men (four did not provide information on gender) with a mean age of 35.04 years (SD $=11.77, n=509$ as 24 participants did not report age). All participants were residents of Brazil who were proficient in Portuguese. Over half of the sample reported their ethnicity to be white $(n=274,51.5 \%)$. More details about the demographic characteristics of the sample after data cleaning are provided in the results section.

\section{Measures}

Expressions of Spirituality Inventory- Revised (ESI$\mathrm{R}$; MacDonald 2000a, 2000b). The ESI-R is a 32 item short form of an original 100-item measure which was constructed to operationalize an empirically derived five dimensional model of spirituality (MacDonald, 2000a, $2000 \mathrm{~b})$. Thirty of the items are evenly devised across the five dimensions and two are used for the assessment of face validity (i.e., the respondent's perception of the test as being a valid measure of spirituality) and honesty of responding, respectively. The dimensions are called Cognitive Orientation toward Spirituality
(COS; belief about the existence and relevance of spirituality to identity and daily functioning), Experiential/ Phenomenological Dimension (EPD; spiritual experience), Existential Well-Being (EWB; sense of life meaning, well-being, and the capacity to effectively handle adversity), Paranormal Beliefs (PAR; belief in the existence of paranormal and especially parapsychological phenomena), and Religiousness (REL; intrinsic religious orientation including engagement in religious behaviors such as prayer, meditation, and attendance of religious services). The test utilizes a five-point response scale ranging from 0 (Strongly Disagree) to 4 (Strongly Agree) which respondents use to rate the extent to which they agree each item as being reflective of their own attitudes, beliefs, behaviors, and experiences as they relate to spirituality. Research has provided support for the reliability and validity of the ESI-R dimensions with different cultural samples (MacDonald et al., 2015; Muhamad et al., 2014; Proyer \& Laub, 2015).

Spiritual Well-Being Scale (SWBS; Paloutzian \& Ellison, 1982; Ellison, 1983). The SWBS is a well known and widely used 20 item measure designed to tap a two dimensional model of well-being. The dimensions are Existential Well-Being (EWB) and Religious Well-Being (RWB). Each dimension is operationalized by a 10 item subscale and the test employs a 6-item response scale. The present study employed a version of the SWBS that was already adapted for use in Brazil (Marques, Sarriera, \& Dell'Aglio, 2009). With Brazilian respondents, Marques et al. (2009) report that the SWBS has acceptable inter-item reliability (e.g., for EWB, RWB, and the total test, alphas are $.92, .85$, and .92 , respectively). The SWBS was included to aid in the evaluation of the convergent and discriminant validity of the ESI-R dimensions. Based upon correlations reported in MacDonald (2000b) using the longer ESI, we expected SWBS-EWB to produce a strong positive correlation with ESI-R EWB. SWBS-RWB was expected to generate its strongest correlation with ESI-R REL, followed by ESI-R COS then ESI-R EPD.

Demographics (e.g., age, gender, race, education) and information on religious affiliations, involvement, and participation (e.g., frequency of participation in spiritual worships/practices) were also obtained with a separate questionnaire.

\section{Procedures}

Translation and Adaptation Procedure for the ESI$R$. Our approach to the adaptation of the ESI-R for a Portuguese speaking Brazilian sample took into consideration the recommendations of Borsa, Damasio and 
Bandeira (2012) and consisted of multiple stages. First, two translators proficient in both English and Brazilian Portuguese independently translated the ESI-R instructions, response scale, and items to Portuguese. Thereafter, the first author synthesized the two translations and then solicited a small sample of 73 Brazilians (mean age $=35.5$ years, $S D=8.17,63 \%$ women, 33\% non-believers) to complete an online review of the ESI-R translation to evaluate comprehensibility of items using a four point rating scale ranging from 0 (no understanding) to 3 (perfectly understandable). They were also invited to provide written suggestions for item revision. Any items which failed three of four criteria (i.e., less than $80 \%$ of evaluators provided a rating of 2 or higher; mean rating falling below 2.4; median rating falling below 2.5; five or more suggestions for revision), were reexamined and revised. Additional content revisions to some items were made in order to best ensure that all items were comprehensible to people of lower educational levels. Subsequent to this, two different translators translated the test from Portuguese back to English and the back-translated version was shared with the test author (i.e., the second author of this paper) for his evaluation and comment. Any items identified as problematic at this stage were then further revised with the help of the translators and/or consulting lay reviewers and the process continued in an iterative fashion until all parties had reached agreement.

Using this process, all items except one were deemed to have been translated satisfactorily. For one item (item 27 belonging to the Experiential/ Phenomenological dimension), there were difficulties in arriving at an acceptable translation, so at the recommendation of the test author, two versions of this item were included in the Portuguese version of the questionnaire in order to permit for statistical evaluation. The second translated version of the item was inserted as item 31 on the test. This item was not used in the scoring of the ESI-R for analyses in the present study. The complete Portuguese version of the ESI-R that was used in this study can be found in the Appendix.

Data gathering. Once translated, the ESI-R along with the SWBS and a short demographic questionnaire were administered to volunteer participants recruited online through social networks by the authors of this study, and responding instruments via Google Forms. Health students and teachers from Universidade Federal de Pernambuco and Faculdade Associação Caruaruense de Ensino Superior, in addition to attendees and workers at professional conference held by the International Transpersonal Association in Brazil in summer 2015 were also solicited for participation. Volunteers from the university/faculty and the conference completed the questionnaires in paper-and-pencil format.

Ethical Considerations. Data were collected within the context of a doctoral research project being conducted by the first author through Post-graduate program in Education of the Federal University of Pernambuco. All participants who volunteered for the study gave informed consent prior to completing the questionnaires; this involved reading and signing a hard copy consent form for those who did the questionnaires in paper-and-pencil. For those who participated online, they first read the consent form and then checked off a box indicating they understood the terms of participation before they completed the questionnaires.

Data Analysis. Before scoring the tests and completing any statistical analyses, the item level data for the ESI-R were thoroughly examined for excessive missing and/or out-of-range scores and for evidence of problematic response patterns (e.g., perseverative or dishonest responding as indicated by the last item on the ESI-R). Cases demonstrating any these difficulties were removed from the dataset. As well, demographic variables were reviewed with particular attention given to age. Since international research standards (e.g., National Institutes of Health in the United States) often identify age 18 as the minimum age appropriate for a person to be able to give informed consent for participation in research (volunteers of an age younger than 18 years generally require informed consent to be obtained from a parent or legal guardian and verbal assent from the participant), participants younger than age 18 and those who did not provide age information were identified and removed from the dataset. Based upon these considerations, a total of 40 cases were excluded, leaving a final cleaned sample of 493 participants.

In terms of demographic characteristics, the final sample was made up of 362 women and 130 men (1 participant did not provide a response) with a mean age of 35.15 years $(S D=11.62$, ranging from 18 to 80$)$. In terms of race, 260 participants were classified as white and 212 as other (21 did not report race). For education, 480 participants reported having undergraduate or graduate level schooling. With regard to geographic location of primary residence, 380 participants reported Northeast Brazil. For 
religious affiliation, Catholicism $(n=189)$ followed by Spiritism ( $n=143$ ) were the most commonly reported. With religious activity, 124 participants reported little to none, 288 reported occasional activity, and 77 reported frequent activity (4 provided no response). Lastly, the number of participants who completed the measures online was 358 while 135 completed the measures in paper-and-pencil form. Prior to completing our main analyses, we compared ESI-R dimension scores for those who completed it online versus paper-and-pencil to ensure there were no systematic differences. Of the five one-way ANOVAs, only the one for ESI-R Paranormal Beliefs came out significant $(F(1$, $491)=5.94, p<.05)$, with the online group obtaining the higher mean score (online group=13.39 vs. paper-and-pencil group $=11.90$ ). Based on this, we concluded that it was safe to combine the two groups into a single sample for the sake of this study.

Planned data analyses aimed at evaluating the ESI-R in terms of its reliability, convergent validity, criterion validity, and factorial validity. The specific types of analyses we completed included (a) descriptive statistics (i.e., means, standard deviations, and minimum and maximum scores), (b) reliability statistics (e.g.,
Cronbach's alpha and corrected item-to-scale correlations), (c) one sample t-tests comparing ESI-R dimensions scores obtained with our Brazilian sample to the scores reported by MacDonald et al. (2015) with eight different cultural samples, (d) product-moment correlations between the ESI-R dimensions and SWBS total and subscale scores, (e) product-moment correlations between the ESI-R dimension scores and demographic variables including religious activity, (f) exploratory principal axis factor analysis of ESI-R items to assess factorial stability, and (g) confirmatory factor analysis testing the goodness-of-fit of the ESI-R to both four and five factor models. All statistics were completed using SPSS (version 21) and AMOS (version 21).

\section{Results}

\section{Descriptive and Reliability Statistics}

Table 1 presents the means, standard deviations, scale level reliabilities and the mean corrected-item-to-scale level correlations for all ESI-R dimensions and SWBS scales for our sample. For both tests, all inter-item consistency coefficients and item to scale level correlations reflect satisfactory reliability.

Table 1. Descriptive and Reliability Statistics for the ESI-R and SWBS

\begin{tabular}{|c|c|c|c|c|c|c|c|}
\hline & \multirow{2}{*}{$\begin{array}{l}\text { No\# of } \\
\text { items }\end{array}$} & \multirow[b]{2}{*}{ Mean } & \multirow[b]{2}{*}{ SD } & \multicolumn{2}{|c|}{ Range } & \multicolumn{2}{|c|}{ Reliability } \\
\hline & & & & Min & Max & Alpha & $\begin{array}{l}\text { Mean CIST } \\
\text { Correlation }\end{array}$ \\
\hline ESI-R Cognitive Orientation toward Spirituality (COS) & 6 & 18.82 & 5.50 & 0 & 24 & .92 & .79 \\
\hline ESI-R Experiential/ Phenomenological Dimension (EPD) & 6 & 15.65 & 6.35 & 0 & 24 & .90 & .72 \\
\hline ESI-R Existential Well-Being (EWB) & 6 & 17.40 & 4.37 & 0 & 24 & .81 & .57 \\
\hline ESI-R Paranormal Beliefs (PAR) & 6 & 12.98 & 6.11 & 0 & 24 & .86 & .64 \\
\hline ESI-R Religiousness (REL) & 6 & 17.40 & 5.79 & 0 & 24 & .89 & .71 \\
\hline SWBS- Existential Well-Being (EWB) & 10 & 47.10 & 7.98 & 19 & 60 & .82 & .51 \\
\hline SWBS- Religious Well-Being (RWB) & 10 & 47.11 & 12.00 & 10 & 60 & .92 & .70 \\
\hline SWBS- Total Test & 20 & 94.21 & 17.13 & 34 & 120 & .90 & .53 \\
\hline
\end{tabular}

Note. $N=493$. For Reliability, Alpha= Cronbach's alpha. Mean CIST correlation= Mean corrected item-to-scale total correlation. For ESI-R EPD, statistics reported in the table are based upon the six original items in the test. When the "alternate" item (i.e., placed as item 31 in the translated test) was used in place of item 27 for reliability analysis, alpha remained the same (.90). For all subsequent statistics on EPD, original items were used.

\section{Comparison to Other Cultural Samples}

In order to get a sense of how our Brazilian sample compares to samples from other cultures, we utilized one-sample t-tests to test for score differences on the ESI-R dimensions using the mean ESI-R scores for the eight cultural samples (Canada, India, Japan, Korea, Poland, Slovakia, Uganda, U.S.) reported in MacDonald et al., (2015). Due to space limitations, we are unable to report those findings in detail here. In general, all but three of the $40 \mathrm{t}$-tests were significant, with the Brazilian sample obtaining the higher score in every instance except one; when compared to the Ugandan sample on ESI-R Religiousness, the Brazilian sample produced a significantly lower score. 


\section{Correlations Between ESI-R Dimensions and SWBS}

Next, we examined the bivariate associations between the ESI-R dimensions and SWBS scales using product-moment correlation. The correlations can be found in Table 2. When just looking at the relations of the ESI-R dimensions to each other, the pattern of inter-correlations shows that all dimensions save Existential Well-Being (EWB) are significantly and positively correlated with one another with correlations ranging from $r=$ .35 between Paranormal Beliefs (PAR) and Religiousness (REL) to $r=.81$ between COS and REL. ESI-R EWB was not significantly correlated with any ESI-R dimension except PAR and the correlation was small and negative $(r=-.14, p<.01)$. In general, this configuration of associations between the ESI-R dimensions is consistent with what has been observed in other research (e.g., MacDonald, 2000b) and with other cultural samples (MacDonald et al., 2015).

Examination of the correlations between the ESI-R dimensions and SWBS shows a pattern of associations supportive of the convergent and discriminant validity of the ESI-R; while all but two of the correlations emerged significant, the most conspicuously elevated correlations emerged between ESI-R REL and SWBS Religious Well-Being $(r=.82, p<.001)$ and between ESI-R Existential Well-Being and SWBS Existential WellBeing $(r=.59, p<.001)$.

Table 2. Product-moment Correlations Between ESI-R Dimensions, and SWBST and Subscale Scores

\begin{tabular}{lccccccc}
\hline \multicolumn{1}{c}{} & $\mathbf{1}$ & $\mathbf{2}$ & $\mathbf{3}$ & $\mathbf{4}$ & $\mathbf{5}$ & $\mathbf{6}$ & $\mathbf{7}$ \\
\hline 1. ESI-R COS & & & & & & & \\
2. ESI-R EPD & $.69^{* * *}$ & & & & & & \\
3. ESI-R EWB & .03 & -.07 & & & & & \\
4. ESI-R PAR & $.49^{* * *}$ & $.56^{* * *}$ & $-.13^{* *}$ & & & & \\
5. ESI-R REL & $.81^{* * *}$ & $.52^{* * *}$ & .00 & $.35^{* * *}$ & & & \\
6. SWBS- EWB & $.32^{* * *}$ & $.19^{* * *}$ & $.59^{* * *}$ & .03 & $.28^{* * *}$ & & \\
7. SWBS-RWB & $.67^{* * *}$ & $.38^{* * *}$ & .06 & $.25^{* * *}$ & $.82^{* * *}$ & $.45^{* * *}$ & \\
8. SWBS-Total & $.62^{* * *}$ & $.35^{* * *}$ & $.32^{* * *}$ & $.19^{* * *}$ & $.70^{* * *}$ & $.78^{* * *}$ & $.91^{* * *}$ \\
\hline Note. N $=493 .{ }^{*} p<.05 ;^{* *} p<.01{ }^{* * *} p<.001$. & & & &
\end{tabular}

\section{Correlations of ESI-R with Religious Activity}

As a test of criterion validity, bivariate correlations were calculated between the five ESI-R dimensions and self-reported religious activity. All five correlations emerged significant with those involving REL $(r=.53, p$ $<.001), \operatorname{COS}(r=.49, p<.001)$, and EPD $(r=.35, p<.001)$ producing the strongest coefficients and those with $\operatorname{EWB}(r=.11, p<.05)$, and PAR $(r=.13, \mathrm{p}<.01)$ reflecting less potent associations.

\section{Analyses with Other Demographic Variables}

Though they are not reported in detail here due to space limitations, correlations between ESI-R dimension scores and the demographic variables were calculated and examined. With age, coefficients ranged in magnitude from $r=.08(p>.05)$ with EWB to $r=.35(p<.001)$ with PAR. Associations with the remaining ESI-R dimensions came out significant but reflect small effect sizes (e.g., COS, $r=.21, p<.001$; EPD, $r=.22, p<.001$; REL, $r=$ $.15, p<.01$ ). With gender (where women were coded 0 and men coded 1$)$, correlations ranged from $r=-.04$ ( $p$ $>.05)$ with PAR and EPD to $r=-.20(p<.001)$ with REL. Of the other three correlations, only COS was significant $(r=$ $-.14, p<.01)$. With education, correlations ranged from $r=$ $-.03(p>.05)$ with REL to $r=.12(p<.01)$ with EPD and PAR. With race (where white was coded 1 and "all other races" coded 0 ), significant coefficients were found with $\operatorname{COS}(r$ $=.17, p<.001), \operatorname{EPD}(r=.19, p<.001)$, and PAR $(r=.22, p$ $<.001$ ). Lastly, with geographic region (where northeast was coded 1 and "not northeast" was coded 0 ), significant but small coefficients were obtained with $\operatorname{COS}(r=-.10, p$ $<.05)$, EPD $(r=-.09, p<.05)$, and PAR $(r=-.15, p<.01)$.

\section{Exploratory Factor Analysis}

As a general test of the factorial validity of the $\mathrm{ESI}-\mathrm{R}$, the 30 items comprising the five dimensions were used in an exploratory principal axis factor analysis. The analysis was pre-set to extract five factors and the resulting factor solution obliquely rotated using the promax procedure. Oblique rotation was used rather than the more commonly employed orthogonal rotation because it is known that the ESI-R dimensions are inter-correlated. Oblique rotations are superior when it is known a priori that the factors are correlated. The pattern matrix for the rotated solution along with the factor correlations can be found in Table 3 .

Examination of the ESI-R solution reveals that elevated loadings (i.e., loadings .30 or higher) were obtained on all five factors with all items generating a high loading on at least one factor. Factor one contains high loadings from all COS and REL items as well as item 22 from the EPD dimension. The second factor houses high loadings from all EPD items. Factor three contains notable loadings from all PAR items. Factor four has high loadings from all EWB items. Finally, factor five has high loadings from five of the six COS items (all but item 16). This factor solution generally reflects the ESI-R dimensional structure and is largely consistent with the exploratory factor results reported in MacDonald et al., (2015) and in MacDonald (2000b) when using the longer ESI. 
Table 3. Exploratory Principal Axis Factor Analysis of ESI-R Items: Pattern Loading Matrix from Promax Rotation of a Five Factor Solution

\begin{tabular}{|c|c|c|c|c|c|}
\hline \multirow{2}{*}{ ESI-R Items } & \multicolumn{5}{|c|}{ ESI-R Factors } \\
\hline & 1 & 2 & 3 & 4 & 5 \\
\hline $\cos 1$ & .56 & -.08 & .04 & .00 & .53 \\
\hline $\cos 6$ & .47 & -.06 & .02 & -.03 & .51 \\
\hline $\cos 11$ & .51 & .14 & .03 & .02 & .34 \\
\hline $\cos 16$ & .45 & .23 & -.02 & .04 & .15 \\
\hline $\cos 21$ & .49 & .21 & -.04 & .06 & .30 \\
\hline $\cos 26$ & .45 & .07 & .04 & -.01 & .46 \\
\hline EPD2 & -.09 & .67 & -.03 & .03 & .18 \\
\hline EPD7 & -.12 & .81 & .17 & -.03 & -.10 \\
\hline EPD12 & .08 & .63 & .11 & .02 & .08 \\
\hline EPD17 & .18 & .70 & -.01 & -.01 & -.01 \\
\hline EPD22 & .30 & .75 & -.22 & .02 & -.08 \\
\hline EPD27 & -.07 & .87 & .12 & -.05 & -.13 \\
\hline EWB3 & -.12 & .01 & .08 & .66 & .00 \\
\hline EWB8 & .02 & -.03 & .04 & .73 & -.03 \\
\hline EWB13 & .02 & .10 & -.05 & .66 & -.09 \\
\hline EWB18 & .03 & -.02 & -.04 & .71 & -.07 \\
\hline EWB23 & -.07 & -.08 & .04 & .65 & .11 \\
\hline EWB28 & .07 & -.00 & -.11 & .45 & .05 \\
\hline PAR4 & -.03 & -.08 & .86 & -.06 & .06 \\
\hline PAR9 & .09 & .11 & .33 & -.13 & .03 \\
\hline PAR14 & -.14 & .08 & .62 & -.02 & .10 \\
\hline PAR19 & .24 & -.10 & .65 & .08 & -.07 \\
\hline PAR24 & -.05 & .10 & .73 & .02 & -.02 \\
\hline PAR29 & .01 & .09 & .85 & .03 & -.04 \\
\hline REL5 & .75 & -.07 & -.13 & -.05 & .04 \\
\hline REL10 & .58 & .14 & .10 & .06 & .11 \\
\hline REL15 & .72 & .02 & -.13 & -.06 & -.03 \\
\hline REL20 & .85 & .02 & .06 & .04 & -.13 \\
\hline REL25 & .78 & -.04 & .08 & -.03 & .11 \\
\hline REL30 & .95 & -.16 & .10 & -.03 & -.13 \\
\hline \multicolumn{6}{|c|}{ Factor Correlations } \\
\hline \multicolumn{6}{|l|}{ Factor 1} \\
\hline Factor 2 & .54 & & & & \\
\hline Factor 3 & .35 & .56 & & & \\
\hline Factor 4 & .04 & -.06 & -.12 & & \\
\hline Factor 5 & .51 & .63 & .48 & .07 & \\
\hline
\end{tabular}

Note. Factor loadings .30 or higher are indicated in bold. For ESI-R and SWBS items, acronym indicates dimension/subscale and number indicates item number on test.

\section{Confirmatory Factor Analyses}

As our final set of statistics, we completed Maximum Likelihood confirmatory factor analyses (CFA) on the ESI-R testing a correlated five factor model reflective of the intended factorial structure of the test along with a correlated four factor model in which COS and REL items were assigned to a unitary factor. In both models, all latent traits (i.e., ESI-R dimensions) were permitted to correlate. The analysis of the four factor model was done as our study and previous research (e.g., MacDonald 2000b; MacDonald et al. 2015) has found that COS and REL are highly correlated and often share high loadings in exploratory analyses. The testing of the two models with the same items and data permits for a direct comparison as they can be considered nested (Kline, 2011). The standardized regression weights (i.e., factor loadings) along with overall model fit indices can be found in Table 4.

In the case of both models, all item level factor loadings emerged significant at $\mathrm{p}<.01$ or lower. As well, item error variances (not reported in the table) came out significant. With respect to the correlations between factors, for the five factor model, all but three correlations were significant. The non-significant correlations involved EWB in all cases (i.e., EWB was not significantly associated with COS, EPD, and REL). In the four factor model, all factor correlations were significant except those between EWB and EPD, and EWB and the combined COS/ REL factor. To assess the stability of parameter estimates, bootstrap analyses were completed. Examination of $90 \%$ bias corrected estimates generated from 1000 bootstrap samples revealed that all parameters remained significant. One change was noted for both the four and five factor models involving the correlation between EWB and EPD. In particular, while this correlation was non-significant in the initial analyses, it emerged significant in the bootstrap analysis for both models $(r=-.10, p<.05$ for both four and five factor models).

Based upon a consideration of the item level statistics alone, it could be argued that both four and five factor models are adequate. Inspection of overall model fit indices, however, reveals that the four factor model demonstrates mixed to poor fit. For instance, chi-square significant, and the Tucker Lewis Index (TLI) and Comparative Fit Index (CFI) produce values below .90. The only index which suggests the model is somewhat adequate is the Root Mean Square Error of Approximation (RMSEA) which is .075 (values less than .08 are generally seen as acceptable). The five factor 
L. X. Lima e Silva et al.

Table 4. Confirmatory Factor Analysis of ESI-R: Standardized Regression Weights and Goodness of Fit Statistics for Four and Five Factor Models

\begin{tabular}{|c|c|c|c|c|c|c|c|c|c|}
\hline & \multicolumn{4}{|c|}{ Correlated Four Factor Model } & \multicolumn{5}{|c|}{ Correlated Five Factor Model } \\
\hline $\cos 1$ & .88 & --- & --- & --- & .88 & --- & --- & --- & --- \\
\hline $\cos 11$ & .85 & --- & --- & --- & .86 & --- & --- & --- & --- \\
\hline $\cos 26$ & .83 & --- & --- & --- & .85 & --- & --- & --- & --- \\
\hline EPD2 & --- & .70 & --- & --- & --- & .71 & --- & --- & --- \\
\hline EPD7 & --- & .76 & --- & --- & --- & .76 & --- & --- & --- \\
\hline EPD27 & --- & .81 & --- & --- & --- & .81 & --- & --- & --- \\
\hline EWB3 & --- & --- & .65 & --- & --- & --- & .65 & --- & --- \\
\hline EWB8 & --- & --- & .72 & --- & --- & --- & .72 & --- & --- \\
\hline EWB13 & --- & --- & .64 & --- & --- & --- & .64 & --- & --- \\
\hline EWB18 & --- & --- & .71 & --- & --- & --- & .71 & --- & --- \\
\hline EWB23 & --- & --- & .66 & --- & --- & --- & .66 & --- & --- \\
\hline EWB28 & --- & --- & .47 & --- & --- & --- & .47 & --- & --- \\
\hline PAR4 & --- & --- & --- & .81 & --- & --- & --- & .81 & --- \\
\hline PAR29 & --- & --- & --- & .89 & --- & --- & --- & .89 & --- \\
\hline REL5 & .61 & --- & --- & --- & --- & --- & --- & --- & .66 \\
\hline REL10 & .79 & --- & --- & --- & --- & --- & --- & --- & .78 \\
\hline REL15 & .60 & --- & --- & --- & --- & --- & --- & --- & .65 \\
\hline REL20 & .75 & --- & --- & --- & --- & --- & --- & --- & .81 \\
\hline REL25 & .82 & --- & --- & --- & --- & --- & --- & --- & .85 \\
\hline REL30 & .73 & --- & --- & --- & --- & --- & --- & --- & .81 \\
\hline$x^{2}$ & \multicolumn{4}{|c|}{1491.01} & \multicolumn{5}{|c|}{1295.03} \\
\hline Df & \multicolumn{4}{|c|}{399} & \multicolumn{5}{|c|}{395} \\
\hline TLI & \multicolumn{4}{|c|}{.87} & \multicolumn{5}{|c|}{.89} \\
\hline $\mathrm{CFI}$ & \multicolumn{4}{|c|}{.88} & \multicolumn{5}{|c|}{.90} \\
\hline RMSEA & \multicolumn{4}{|c|}{$\begin{array}{c}.075 \\
<.001 \cdot 071-079.90 \% \mathrm{C}\end{array}$} & \multicolumn{5}{|c|}{$\begin{array}{c}.068 \\
.064-.072\end{array}$} \\
\hline
\end{tabular}

Note. For both factor models, all regression weights significant at $p=.01$ or lower. Though not included in the table, all error variances in both models were significant at $p=.01$ or lower. For four factor model, all factor correlations significant at $p=.01$ or lower except for those between COS/REL-EWB and EPD-EWB (both $p>05$ ). For five factor model, all factor correlations significant at $p=.01$ or lower except those between EWB-REL, EWB-COS, and EWB-EPD. 
model in contrast shows somewhat better fit; while chi-square is still significant and the TLI falls just below. 90, values for the CFI and RMSEA are reasonably satisfactory, though not excellent. Examination of modification indices and residuals to identify areas of model misfit for the five factor model indicated that items showed a fair degree of intercorrelation not explained by the model and that overall model fit could be improved if several items were permitted to load on more than one factor. Though we gave consideration to testing a respecified model, we elected against doing so as there is an insufficient theoretical basis for doing so and changing a model just for the sake of improving fit based upon statistical considerations alone is not a defendable practice when doing CFA.

A more direct test of the two models can be done by examining the change in chi-square to determine if it is statistically significant. If so, then the model with the lower chi-square can be viewed as superior. In the case of these two models, the difference in chi-square is 195.98. Testing this value with a df of 4 (which is the difference in the degrees of freedom between the two models and is used to evaluate the significance of change in chi-square) reveals that it is statistically significant at $p<.001$. Since the five factor model obtained the lower chi-square value (1295.03 versus 1491.01 for the four factor model), it can be concluded that the five factor model is the better of the two models. These findings are completely consistent with MacDonald et al., (2015) in their analysis of the quality of model fit for four and five factor models with multiple cultural samples.

\section{Discussion and conclusion}

Overall, our findings indicate that the Brazilian Portuguese translation of the ESI-R demonstrates satisfactory reliability and generally adequate convergent, discriminant, criterion, and factorial validity with a Brazilian sample and does so in a manner that is consistent with published cross-cultural research (e.g., MacDonald et al., 2015; Proyer \& Laub, 2015). As such, it seems that our study amply justifies further use and investigation of the ESI-R in Brazil using the translation of the test that we developed. Nevertheless, though there is fair support for the structural invariance of the test, there are indications that the ESI-R does not produce scores that show measurement invariance across cultures. This was primarily evidenced in the statistically significant differences found with the one-sample $\mathrm{t}$-tests comparing the ESI-R dimension scores from our sample to the mean scores for eight different cultural samples used by MacDonald et al. (2015). Though these comparisons do not provide as strong of a test of measurement invariance as would be done through the use of multiple group CFA analysis, Byrne and Watkins (2003) offer compelling argumentation indicating that statistically significant differences in item and/or scale scores as a function of an important grouping variable serve as a meaningful indicator of measurement non-invariance. Consequently, it appears that the conclusions of MacDonald et al. (2015) are applicable to our study; spirituality may be viewed as a viable concept which empirically behaves in a similar manner across cultures...At the same time, the results indicate quite clearly that spirituality is not a concept that 'transcends' culture and holds a firm universality of meaning. Rather, it seems that opposite holds true; the specific meaning ascribed to spirituality appears to be intrinsically bound by culture and cannot be fully understood without consideration given to cultural factors (MacDonald et al., 2015, p. 32).

Extending from this, MacDonald et al.'s (2015) main recommendation appears to be quite germane, namely, that the use of standardized self-report measures developed in one culture to study spirituality in a different culture should be done with care and researchers should not only ensure that the instruments they use demonstrate adequate psychometric properties but also seek to augment data gathering methods by including culturally specific content so as to best capture the unique features of spirituality as they are actually expressed by members of that culture.

\section{Limitations of the Study and Directions for Future Research}

Though the findings of our study are generally supportive of the ESI-R, this investigation suffers from few limitations which must be noted. First, we utilized a convenience sample where the majority of respondents came from just one of the five Brazilian regions (about $77 \%$ of sample reported coming from the Northeast). In addition, women and highly educated people appear to be over-represented in our sample. As well, a sizable number of participants were attendees or workers at a conference for an international association that advocates for the inclusion of spirituality in academic, social, and professional activities. In light of these factors, it is reasonable to view our sample as not being 
representative of the Brazilian population as a whole. Second, it is possible that our translation and adaptation of the ESI-R may suffer from some inadequacies that can only be addressed by having independent researchers review and improve upon our translated version of the test. Finally, though it was not a pervasive problem, there was some indication that the use of two different questionnaire administration forms (online versus paper-and-pencil) may have had an influence on participant responses, especially for Paranormal Beliefs.

Given these considerations, future research should aim at evaluating the quality of our translation and examining validity of the ESI-R though the use of samples that more accurately reflect the cultural, religious, and socio-economic diversity of Brazilian people with a standardized data gathering methodology.

\section{References}

Affeldt, D. L., \& MacDonald, D. A. (2010). The relationship of spirituality to work and organizational attitudes and behaviors in a sample of employees from a health care system. Journal of Transpersonal Psychology, 42(2), 192-208. Retrieved from http://atpweb.org/jtparchive/trps-42-10-02-192.pdf

Bliss, D. L. (2011). Sexual orientation differences in spirituality in a sample of Alcoholics Anonymous members: Implications for practitioners. Journal of Gay and Lesbian Social Services, 23(3), 335-350. doi: 10.1080/10538720.2011.588928

Borsa, J. C., Damasio, B. F., \& Bandeira, D. R. (2012). Cross-cultural adaptation and validation of psychology instruments. Paideia, 22, 423-432. doi: 10.1590/S0103-863X2012000300014

Byrne, B. M., \& Watkins, D. (2003). The issue of measurement invariance revisited. Journal of Cross Cultural Psychology, 34(2), 155175. doi: 10.1177/0022022102250225

Carvalho, A. F., Taunay, T. C., \& Gondim, F. (2012). Disponibilidade de instrumentos validados para o estudo da religiosidade em amostras Brasileiras. Archives of Clinical Psychiatry, 39(6), 208. Retrieved from http://www.scielo.br/pdf/rpc/v39n6/pt_06.pdf

Curcio, C. S. S., Lucchetti, G., \& Moreira-Almeida, A. (2015). Validation of the Portuguese version of the Brief Multidimensional Measure of Religiousness/Spirituality (BMMRS-P) in clinical and non-clinical samples. Journal of Religion and Health, 54(2), 435-448. doi: 10.1007/s10943-013-9803-1

Ellison, C. W. (1983). Spiritual well-being: conceptualization and measurement. Journal of Psychology and Theology, 11, 330-340. Retrieved from http://journals.biola.edu/jpt/volumes/11/issues/4/articles/330

Fetzer Institute, National Institute on Aging Working Group (1999). Multidimensional measurement of religiousness/spirituality for use in health research. Kalamazoo, MI, USA: Fetzer Institute.

Gabriel, V., \& Jezek, S. (in press). Factor validity and internal consistency of the ESI: the Czech context. International Journal of Transpersonal Studies.

Heintz, L. M., \& Baruss, I. (2001). Spirituality in late adulthood. Psychological Reports, 88, 651-654. doi: 10.2466/pr0.2001.88.3.651
Henrich, J., Heine, S. J., \& Norenzayan, A. (2010). The weirdest people in the world? Behavioral and Brain Sciences, 33, 61-83. doi: 10.1017/S0140525X0999152X

Huber, J.T., \& MacDonald, D. A. (2012). An investigation of the relations between altruism, empathy, and spirituality. Journal of Humanistic Psychology, 52(2), 206-221. doi: 10.1177/0022167811399442

Kassab, V. A., \& MacDonald, D. A. (2011). Examination of the psychometric properties of the Spiritual Fitness Assessment. Journal of Religion and Health. 50(4), 975-985. doi: 10.1007/ s10943-010-9325-z

Kline, R. B. (2011). Principles and practices of structural equation modeling (3rd ed.). New York, NY, USA: Guilford.

Lopez, E., Jodar, R., \& MacDonald, D. A. (in press). Psychometric properties of a Spanish adaptation of the Expressions of Spirituality Inventory- Revised. International Journal of Transpersonal Studies.

Lucchetti, G., Lucchetti, A. L., \& Vallada, H. (2013). Measuring spirituality and religiosity in clinical research: A systematic review of instruments available in the Portuguese language. Sao Paulo Medical Journal, 131(2), 112-122. doi: 10.1590/S1516-31802013000100022

MacDonald, D. A. (2000a). The Expressions of Spirituality Inventory: test development, validation, and scoring information. Test Manual. Retrieved from https://ckannet-storage.commondatastorage.googleapis.com/2015-01-04T21:42:45.640Z/esimanual.pdf

MacDonald, D. A. (2000b). Spirituality: description, measurement and relation to the Five Factor Model of personality. Journal of Personality, 68(1), 153-197. doi: 10.1111/1467-6494.t01-1-00094

MacDonald, D. A. (2009). Identity and spirituality: conventional and transpersonal perspectives. International Journal of Transpersonal Studies, 28, 86-106. Retrieved from http://digitalcommons.ciis.edu/ ijts-transpersonalstudies/vol28/iss 1/9/

MacDonald, D. A., Friedman, H. L., Brewczynski, J., Holland, D., Salagame, K. K. K., Mohan, K. K., ... Cheong, H. W. (2015). Spirituality as a scientific construct: tTesting its universality across cultures and languages. PLoS One, 10(3), e0117701. doi:10.1371/ journal.pone.0117701

MacDonald, D. A., \& Holland, D. (2002a). Spirituality and boredom proneness. Personality and Individual Differences, 32(6), 1113-1119. doi: 10.1016/S0191-8869(01)00114-3

MacDonald, D. A., \& Holland, D. (2002b). Spirituality and complex-partial epileptic-like signs. Psychological Reports, 91, 785-792. doi: 10.2466/pr0.2002.91.3.785

MacDonald, D. A., \& Holland, D. (2002c). Examination of the psychometric properties of the Temperament and Character Inventory SelfTranscendence dimension. Personality and Individual Differences, 32(6), 1013-1027. doi: 10.1016/S0191-8869(01)00107-6

MacDonald, D. A., \& Holland, D. (2003). Spirituality and the MMPI2. Journal of Clinical Psychology, 59(4), 399-410. doi: 10.1002/ jclp. 10047

Marques, L. F., Sarriera, J. C., \& Dell'Aglio, D. D. (2009). Adaptação e validação da Escala de Bem-estar Espiritual (EBE). Avaliação Psicológica, 8(2), 179-186. Retrieved from de http://pepsic.bvsalud.org/scielo.php?script=sci_arttext\&pi$\mathrm{d}=$ S1677-04712009000200004\&lng=pt\&tIng=pt.

Mendez, D. M, \& MacDonald, D. A. (2012). Spirituality and the MMPI-2 Restructured Clinical Scales. International Journal of Transpersonal Studies, 31(1), 1-10. Retrieved from http://digitalcommons.ciis.edu/ ijts-transpersonalstudies/vol31/iss $1 / 3 /$ 
Psychometric examination of a Brazilian adaptation of the Expressions of Spirituality Inventory - Revised

Migdal, L., \& MacDonald, D. A. (2013). Clarifying the relation between spirituality and well-being. Journal of Nervous and Mental Disease, 201(4), 274-280. doi: 10.1097/NMD.0b013e318288e26a

Moreira-Almeida, A., Pinsky, I., Zaleski, M., \& Laranjeira, R. (2010). Religious involvement and sociodemographic factors: a Brazilian national Survey. Revista de Psiquiatria, 37(1) 12-15. doi: 10.1590/ S0101-60832010000100003

Muhamad, H., Roodenburg, J., \& Moore, D. W. (2014). The Expressions of Spirituality Inventory: Evidence for the cross cultural validity in a Malaysian context. Journal of Transpersonal Psychology, 46(1), 58-71. Retrieved from http://atpweb.org/jtparchive/trps-46-14-01-058.pdf
Paloutzian, R. F., \& Ellison, C. W. (1982). Loneliness, spiritual well-being, and quality of life. In L. A. Peplau and D. Perlman (Eds.), Loneliness: a sourcebook of current theory, research, and therapy (pp. 224-237). New York, NY, USA: Wiley.

Proyer , R. T., \& Laub, N. (2015). The German-language version of the Expressions of Spirituality Inventory- Revised: adaptation and Initial Validation. Current Psychology, 36(1), 1-13. doi 10.1007/ s12144-015-9379-x

Saucier, G., \& Skrzypinska, K. (2006). Spiritual but not religious? Evidence for two independent dispositions. Journal of Personality, 74(5), 1257-1292. doi: 10.1111/j.1467-6494.2006.00409.x

Leonardo Xavier de Lima e Silva, Doutorando em Educação pela Universidade Federal de Pernambuco (UFPE), é Analista Ministerial em Psicologia do Ministério Público do Estado de Pernambuco (MPPE). Endereço para correspondência: Rua Otávio Mangabeira, 19, casa 2, Vera Cruz, Camaragibe (PE), CEP: 54786-480. E-mail: leopsixavier@gmail.com

Douglas A. MacDonald, Ph.D em Psicologia Clínica, pela University of Windsor (UW), Ontario (Canadá), é Professor Associado de Psicologia do College of Liberal Arts and Education, University of Detroit Mercy (UDM), Detroit (Estados Unidos da América). E-mail: macdonda@udmercy.edu

Djailton Pereira da Cunha, Doutor em Educação pela Universidade Federal de Pernambuco (UFPE) e Doutor em Sciences de L'éducation Pela Université Lumière Lyon2 (França). E-mail: djailtoncunha@uol.com.br

Aurino Lima Ferreira, Pós-doutorado em Educação pela École Supérieure du Professorat et de l'Éducation Lyon 1 (ESPE/Lyon 1)

(França), Doutor em Educação pela Universidade Federal de Pernambuco (UFPE), é Professor Adjunto da Universidade Federal de Pernambuco (UFPE) e do Programa de Pós-graduação em Educação da Universidade Federal de Pernambuco (UFPE). E-mail: aurinolima@gmail.com

Recebido em 17.Abr.16 Revisado em 25.Mar.17 Aceito em 12.Jun.17 


\title{
Appendix
}

\author{
Brazilian Version of the ESI-R \\ Inventário de Expressões de Espiritualidade - Revisado (ESI-R-BR; MacDonald, 2000)
}

Este questionário diz respeito às suas experiências, atitudes, crenças e práticas de vida relacionadas à espiritualidade. Abaixo são apresentadas várias afirmações. Leia cada uma delas cuidadosamente. Usando as opções de concordância nas colunas à direita, avalie e assinale até que ponto você concorda com cada afirmação, indicando o quanto ela se aplica a você. Não há respostas certas ou erradas. Por favor, responda cada afirmação da maneira mais sincera possível.

O número 0 indica "Discordo Fortemente"; 1 indica "Discordo"; 2 "Neutro"; 3 "Concordo"; 4 "Concordo Fortemente".

\begin{tabular}{|c|c|c|c|c|c|}
\hline & DF & D & $\mathbf{N}$ & C & CF \\
\hline 1. A espiritualidade é uma parte importante de quem eu sou como pessoa. & 0 & 1 & 2 & 3 & 4 \\
\hline 2. Já tive uma experiência em que eu parecia estar intimamente ligado(a) a todas as coisas. & 0 & 1 & 2 & 3 & 4 \\
\hline 3. Sempre parece que estou fazendo as coisas da maneira errada. & 0 & 1 & 2 & 3 & 4 \\
\hline 4. É possível se comunicar com os mortos. & 0 & 1 & 2 & 3 & 4 \\
\hline 5. Eu acredito que frequentar cultos ou práticas religiosas é importante. & 0 & 1 & 2 & 3 & 4 \\
\hline 6. A espiritualidade é uma parte essencial da existência humana. & 0 & 1 & 2 & 3 & 4 \\
\hline 7. Já tive uma experiência onde eu parecia ir além do tempo e do espaço. & 0 & 1 & 2 & 3 & 4 \\
\hline 8. Eu não me sinto confortável comigo mesmo. & 0 & 1 & 2 & 3 & 4 \\
\hline 9. Eu acredito que bruxaria existe. & 0 & 1 & 2 & 3 & 4 \\
\hline 10. Eu tenho um sentimento de proximidade com um Ser Superior. & 0 & 1 & 2 & 3 & 4 \\
\hline 11. Estou mais consciente das minhas escolhas de vida por causa da minha espiritualidade. & 0 & 1 & 2 & 3 & 4 \\
\hline $\begin{array}{l}\text { 12. Eu já tive uma experiência mística, ou seja, uma experiência espiritualmente significativa que parecia ir além do } \\
\text { entendimento humano. }\end{array}$ & 0 & 1 & 2 & 3 & 4 \\
\hline 13. Muito do que eu faço na vida parece feito por obrigação, e não de forma espontânea. & 0 & 1 & 2 & 3 & 4 \\
\hline 14. É possível adivinhar o futuro. & 0 & 1 & 2 & 3 & 4 \\
\hline 15. Eu me vejo como uma pessoa voltada para a religião. & 0 & 1 & 2 & 3 & 4 \\
\hline 16. Eu tento considerar todos os elementos de um problema, incluindo os aspectos espirituais, antes de tomar uma decisão. & 0 & 1 & 2 & 3 & 4 \\
\hline 17. Já tive uma experiência de união com uma Força maior do que eu. & 0 & 1 & 2 & 3 & 4 \\
\hline 18. Minha vida é frequentemente problemática. & 0 & 1 & 2 & 3 & 4 \\
\hline 19. Eu não acredito em espíritos ou fantasmas. & 0 & 1 & 2 & 3 & 4 \\
\hline 20. Eu vejo Deus ou um Poder Superior presente em tudo que faço. & 0 & 1 & 2 & 3 & 4 \\
\hline 21. Minha vida tem se beneficiado da minha espiritualidade. & 0 & 1 & 2 & 3 & 4 \\
\hline 22. Eu já tive uma experiência na qual tudo parecia divino. & 0 & 1 & 2 & 3 & 4 \\
\hline 23. Eu me sinto tenso(a) com frequência. & 0 & 1 & 2 & 3 & 4 \\
\hline 24. Eu acho que a psicocinese, ou seja, mover objetos com a força da mente é possível. & 0 & 1 & 2 & 3 & 4 \\
\hline 25. Eu pratico alguma forma de oração. & 0 & 1 & 2 & 3 & 4 \\
\hline 26. Eu acredito que dar atenção ao próprio crescimento espiritual é importante. & 0 & 1 & 2 & 3 & 4 \\
\hline 27. Já tive uma experiência na qual eu parecia ir além da percepção normal que tenho de mim mesmo(a). & 0 & 1 & 2 & 3 & 4 \\
\hline 28. Eu sou uma pessoa infeliz. & 0 & 1 & 2 & 3 & 4 \\
\hline 29. É possível sair do próprio corpo. & 0 & 1 & 2 & 3 & 4 \\
\hline 30. Eu acredito que Deus ou um Poder Superior é responsável pela minha existência. & 0 & 1 & 2 & 3 & 4 \\
\hline 31. Este questionário parece estar medindo espiritualidade. & 0 & 1 & 2 & 3 & 4 \\
\hline 32. Eu respondi a todas as afirmações com sinceridade. & 0 & 1 & 2 & 3 & 4 \\
\hline
\end{tabular}

Note: Alternative to the item 27: "Já tive uma experiência em que eu me percebia espiritualmente ampliado(a)/elevado(a)" . Alpha's coefficient with this option was equal to original one (.90). 